\title{
PIV 法と画像処理を用いた成層水中の流動・混合解析 \\ ANALYSES OF WIND-INDUCED FLOW AND MIXING IN STRATIFIED WATER BODY USING IMAGE PROCESSING AND PIV METHODS
}

\author{
新谷哲也 ${ }^{1} \cdot$ 梅山元彦 $^{2}$ \\ Tetsuya SHINTANI, Motohiko UMEYAMA \\ 1 正会員 工修 東京都立大学大学院助手 工学研究科土木工学専攻 ( $\mathrm{T}$ 192-0397 八王子市南大沢 1-1) \\ 2 正会員 Ph.D. 東京都立大学大学院教授 工学研究科土木工学専攻 ( $\bar{T}$ 192-0397八王子市南大沢 1-1)
}

\begin{abstract}
Experimental and numerical investigations were conducted in order to understand the windinduced flow and mixing in a closed stratified water body. The two-layer density model was provided in a two-dimensional wind flume. Measurements of conductivity at several vertical points were performed, and the result of the density measurements was compared with the luminance value obtained by the image processing technique. The distributions of luminance were comparable to that of conductivity. The PIV method was also used to measure the two-dimensional velocity field near the density interface. The velocity field by the PIV was compared with the numerical results by the $k-\epsilon$ model with the TVD-MUSCL scheme. It was found that the major feature of the velocity field could be reproduced qualitatively by the present numerical model.
\end{abstract}

Key Words: stratified water body, wind stress, PIV method, image processing technique, MUSCL scheme

\section{1.はじめに}

湖や貯水池等の成層化した閉鎖性水域内の移流・拡散 現象は, 主に水面に作用する風応力によって引き起こ される．特に，風による成層内の運動や成層境界の破 壊は水域内に水質変化をもたらすため, 水質を把握し 管理するためには水域内の挙動を予測することが重要 な課題となる．風が原因で起こる成層の挙動に関する 研究は, 比較的古くから行われてきており，その中心 テーマは密度境界面の 1 次元的な変動（低下）である 連行現象であった。この問題に関する研究では, 室内実 験 1) や現地観測 2) 等のデータが用いられ, Richardson 数に基づく連行則が提案されてきた. 連行現象を扱う 実験では, 密度を測定する必要があるために電気伝導 度計が用いられ，上下にトラバースすることで鉛直密 度分布の変化が測定されてきた. 流速に関しては, ホッ トフィルム流速計 ${ }^{3)}$ 等が用いられ, 連行メカニズムに 関連する乱れ及び平均流速が測定されてきた。 ところ で, 現象が比較的穏やかな実験においては, 鉛直方向 の多点で流速や密度計測にある程度時間を要しても定 常的と見なして，結果を評価してきた。しかしながら， 実際の成層化した閉鎖性水域において大規模な水質变
化を引き起こす下層水の湧昇現象は, 密度境界面の運 動が非常に早いために定常として扱うことができない. そのため, そのような実験をする場合においては, 一 点計測の測定器を上下に移動させる方法では現象をと らえることが非常に困難になってくる. 尹 ${ }^{4)}$ は, 下層 水の湧昇が生じる条件下で, 水槽中央での鉛直流速分 布をレーザードップラー流速計を用いて計測を行い成 功している. しかしながら, 涌昇現象を考えたとき, そ れは 1 次元的な現象ではなく, 水槽内では 2 次元的に 起こるため, もはや一点計測で涌昇現象を議論するこ とはあまり意味がなくなってきている.

近年, 密度測定に関して著者らは, デジタルビデオ カメラを用いた画像解析によって得られる輝度值から 密度変化を予測する方法で密度の 2 次元的な把握を試 みている，この方法によって，2成層水域における中 間密度層の発達特性 ${ }^{5}$ ), 3 成層水域における密度境界 面の非定常運動及び各層の湧昇限界 ${ }^{6)}$, 湧昇域が斜面 地形の場合の湧昇混合状況特性 7) を明らかにしてきた. 今回は, 画像処理による密度測定の精度を確認するた めに, 多チャンネル電気伝導度計を用いた実験をビデ オ撮影と同時に行った。 それを使って時々刻々変化す 
る密度と輝度值に関する鉛直分布の対応関係を詳細に 調べることにする．また，以前の研究において，現象 の早さゆえに電磁流速計やレーザードップラー流速計 を用いての湧昇水塊内の流速を測定することはできな かった．近年では， 2 次元，もしくは 3 次元的に流動 を測定できる PIV 法が開発され様々な分野で成果を上 げてきている。この方法を用いれば湧昇現象に関して 密度のみならず流速分布の 2 次元的把握も同時に可能 となるはずである，しかしながら，現在まで成層流の PIV による測定例は非常に少なく，その適用性の確認 が十分になされていないように思狆る。

そこで, 本研究では, 新谷ら 7) が行った実験を再現 し, PIV 法を適用して密度境界面付近の流速測定を試 みた. PIV 法で測定された流速分布の結果は, 数值計 算で得られた流速分布との比較を中心に検討を行った.

\section{2. 実験法}

風洞実験は, 長さ $600 \mathrm{~cm}$, 幅 $15 \mathrm{~cm}$, 高さ $35 \mathrm{~cm}$ の 2 次 元水槽を用いた ${ }^{7)}$. 斜面を使った実験（PIV 計測）で は風上側に厚さ $1 \mathrm{~cm}$ の透明アクリル製板を勾配 $1 / 5$ で 設置した．水槽内の成層構造は，上下層の厚さを $17 \mathrm{~cm}$ づつの 2 成層構造とした. 水面に作用させる風応力は, すべての実験を通して一定とした．風速は 1 分間かけて 徐々に増加させ，最終的に風洞内の最大風速を $6.5 \mathrm{~m} / \mathrm{s}$ になるまで上げた．このとき水槽中央部分での水面に おける摩擦速度は $1.1 \mathrm{~cm} / \mathrm{s}$ であった。測定時間は全て のケースで 30 分とし, 初期の 10 分間のみ風を吹かせ た.デジタルビデオカメラを用いた画像解析によって 密度を計測するために，下層水をウォーターブルーで 着色した．また，上層水には，風波の発生を抑えるた めの界面活性剤を混入させた。

\section{（1）撮影法及び画像解析法}

ここでは, 実験水槽の撮影法と画像処理法を簡単に説 明する．撮影は外部から光が入らない状況で，水槽の裏 側に設置した光源（蛍光灯）からの透過光を逆側に設置 したデジタルビデオカメラ (TVR-900 : SONY) で撮影 した. デジタルビデオカメラは，画像に奥行き方向の影 響が現れにくいようにカメラを水槽から $2 \mathrm{~m}$ 離して設 置した ${ }^{5)}$. 撮影の際は，透過光のノイズによる空間的 な不均一を極力抑えるために，光源からの光を一度発 砲スチロール製のホワイトボードで反射させ，さらに その光が水槽の裏側に貼り付けた半透明の拡散フィル ターを通過するようにした．映像は $1 / 30 \mathrm{~s}$ の間隔で DV テープに記録しているが，本解析では DV ボードを組 み込んだコンピュータによって 1 秒ごとの静止画像に 変換した，その後は，画像解析ソフト $(\operatorname{Cosmos} 32$ : 株 式会社ライブラリー) を用いてこれらの静止画を 8 ビッ
卜 $(256$ 階調 $)$ の輝度分布図へと変換し，さらに実際の 寸法に対応させるための座標変換を施して図化した.

\section{(2) 多チャンネル電気伝導度計による計測}

これまでの研究 5) では, 3 本の電気伝導度計を自動 昇降機を用いて上下にトラバースさせて密度の鉛直分 布を測定していた．しかしながら，この方法では電気 伝導度計を時間をかけて移動させねばならず，測定点 が多い場合には，同一断面において上と下で大きな時 間差が生じてしまっていた，従って，連行などのゆっく りとした現象における鉛但密度分布の測定は可能であ るが，湧昇や内部セイシュのような非定常現象を捉え ることはできなかった. そこで，今回固定式 16 チャン ネル（16 点同時計測可能）電気伝導度計を用いて密度 分布を測定した. 電気伝導度計のプローブの大きさは, 縦 $1.5 \mathrm{~cm}$, 横 $3 \mathrm{~cm}$, 厚さ $4.5 \mathrm{~mm}$ の直方体であり, この 直方体の一番小さな面に 2 本の電極が $6 \mathrm{~mm}$ 間隔で取り 付けられている．鉛直分布を測定する場合には，流動 を阻害しないように 15 個のプローブを鉛直に $2 \mathrm{~cm}$ 間 隔でガラス壁面に貼り付けた，電気伝導度は，塩分濃 度だけではなく温度変化によっても值が変化するため に補正が必要である．そこで, 残りの 1 個のプローブ を塩分濃度変化がない場所に設置し, 実験中の電気伝 導度を測定し，実験後に 15 チャンネルの測定值の補正 を行った。

\section{(3)PIV 法}

今回の実験では，流速測定のためにはじめて PIV 法 を用いた．図-1に示すようにパルスレーザー発射装置 (NewWave 社製 : Solo PIV II-15) から出たレーザーは アクリル性斜面の下方の水槽底部に固定されたシリン ドリカルレンズ (円形断面のガラス棒) で屈折して斜面 近傍にレーザーシートを形成する．レーザーシートに 映し出された粒子はパルスレーザー発射装置と連動し たC C Dカメラ（Roper 社製 : ES1.0）によって撮影さ れる. 撮影画像は, リアルタイムでフレームグラバー

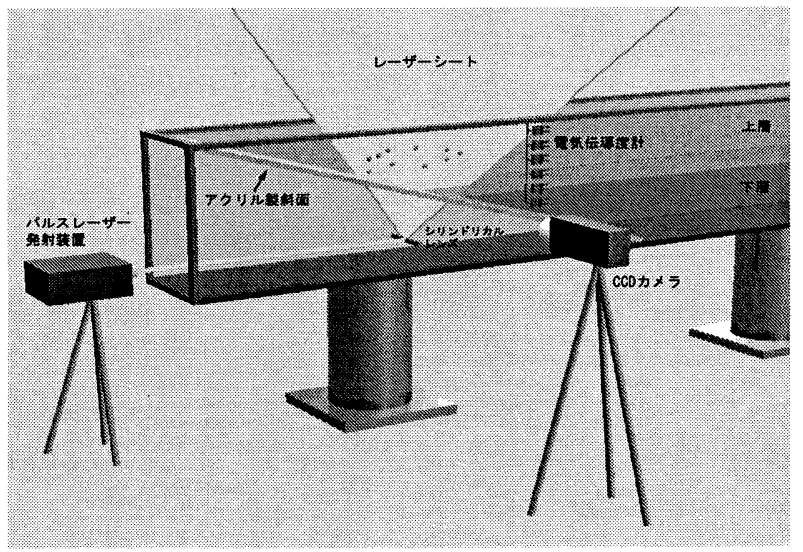

図-1：実験装置（斜面部分） 
ボードを通してコンピューターに取り込まれる。この デジタル画像は不必要部分の除去を行った後, 相互相 関アルゴリズムに基づいて作成したプログラムで処理 することで流速データに変換できる. 一台の CCD カメ ラ（解像度 $1008 \times 1018$ ピクセル）で正確な流動・乱れ を測定するためには $10 \mathrm{~cm} \times 10 \mathrm{~cm}$ 程度の範囲が限度で あることを考慮し, 撮影箇所として初期の密度境界面 と斜面が交差する部分の風上側（風上端から $87 \sim 97 \mathrm{~cm}$ 付近）を選んだ. その結果, 1 ピクセルに対応する領域 の大きさは約 $0.13 \mathrm{~mm} \times 0.13 \mathrm{~mm}$ となった. PIV を用 いて測定を行う際には, 水槽内に白色水性ペイントの 希釈液を上層と下層に少量混入させた。

\section{3. 数值計算法}

水槽内の密度流を $k-\epsilon$ 乱流モデルを使って計算する. 必要となる基礎方程式は, 連続式, 運動方程式, 密度 の輸送方程式及び $k$ と $\epsilon$ の輸送方程式であり, 詳細に ついては新谷ら ${ }^{6)}$ を参照して頂きたい.

本研究では, 基礎方程式をスタッガード格子に基づい て離散化し, 数值解法に有限体積法に基づく半陰解法の SIMPLE 法を用いて解を求めた. 本研究においては数 值拡散の影響を減らすために移流項の離散化に TVDMUSCL 法を用いた。この方法ではオーバーシュートや アンダーシュートなどの数值振動が生じないため, 乱 流エネルギー $k$ やその散逸率 $\epsilon$ の輸送方程式の移流項 にも安定して用いることができる. 計算対象領域は, 水 平・鉛直方向とも等間隔格子で離散化した. 今回は狭い 領域で PIV の測定結果と比較するために以前 ${ }^{6)}$ よりも 水平解像度を多く設定し, 水平を 468 メッシュ, 鉛直 を 34 メッシュ $(\Delta x=1.25 \mathrm{~cm}, \Delta y=1 \mathrm{~cm})$ に離散化して 計算を行った，風上側に設置した斜面は，階段形状の 境界で近似した。 また, 時間ステップは約 $\Delta t=0.003$ 秒として計算を行った.

\section{4. 画像処理と電気伝導度計の比較結果}

画像処理によって得られる輝度分布と多チャンネル 電気伝導度計によって得られる密度分布の比較を行い, 両者の対応関係を調べた結果について述べる. 実験は 斜面なし, 上下層密度差 $0.0025 \mathrm{~g} / \mathrm{cm}^{3}$ の条件で行った. 比較部分は, 風上端から $10 \mathrm{~cm}$ の位置における両者の 鉛直分布とした. 図-2 は, 送風開始後 60 秒, 120 秒, 180 秒， 240 秒経過したときの輝度と密度の鉛直分布を 比較したものである. 輝度分布には, 細かいノイズが 生じている. また, 密度境界面付近の密度変化の再現 性は $\mathrm{T}=180 \mathrm{~s}$ や $240 \mathrm{~s}$ でやや十分でないものの, どの時 間においても密度境界面の位置, 密度境界面下側の密 度低下の様子を良好に表している。

図-3 は, 送風開始後 300 秒までの輝度と密度の鉛直 分布に関する時間変化をまとめて示したものである. 縦
軸は水深で横軸は経過時間を示している，送風開始後 190s と 230s での上昇ピークや 270 秒後の密度境界面が 降下する様子など, 非定常な成層の運動が電気伝導度 でも輝度でもとらえられていることがわかる：このこ とから, 輝度分布によって得られる值は密度分布とし て代用できる可能性が十分にあることがわかる．今回 の比較では, 初期色素濃度や光源（バックライト）強度 による影響は考慮していないが，これらの最適な組み 合わせを探せばより良い結果が得られる可能性がある.
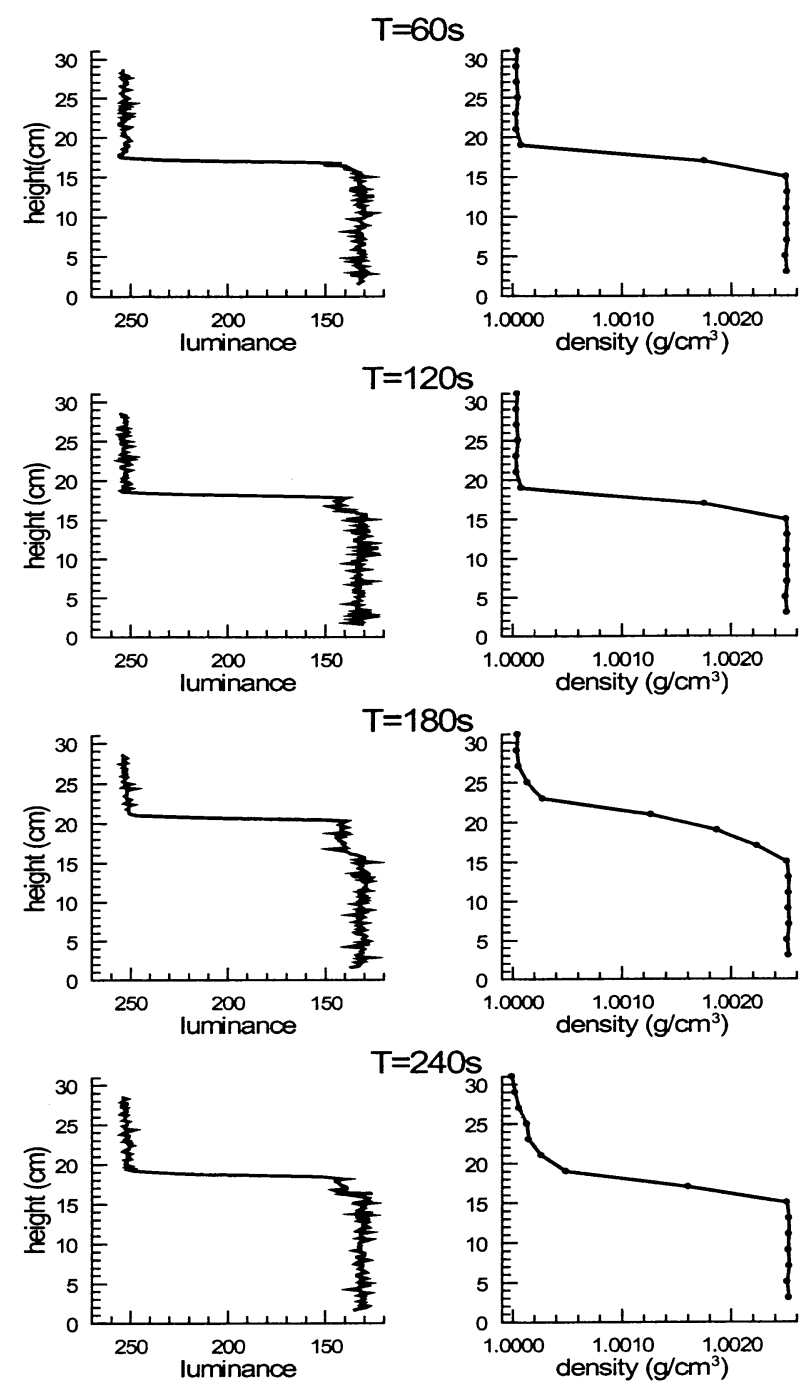

図-2 : 輝度值（左）と密度

（右）の鉛直分布の比較
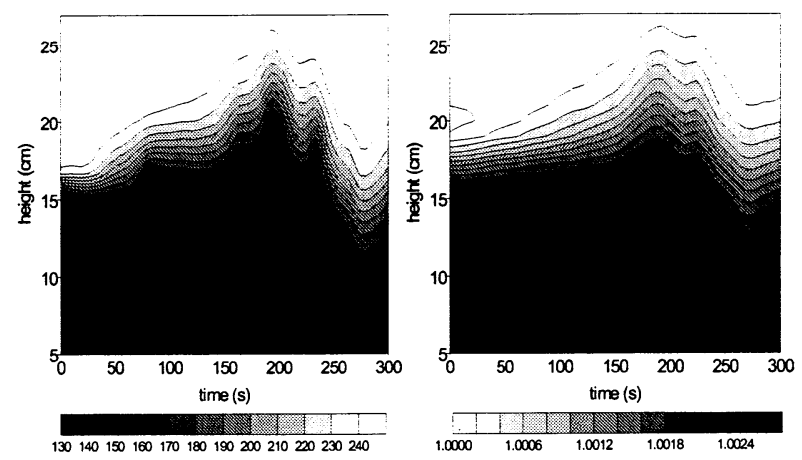

図-3: 輝度值（左）と密度（右）の時間変化の比較 
(a)

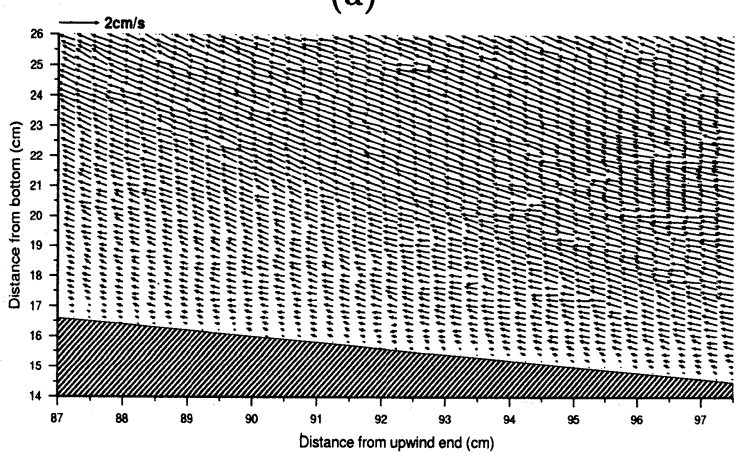

(b)

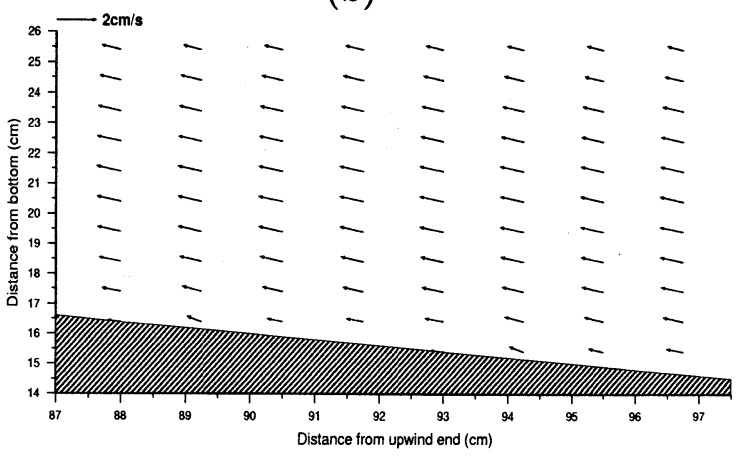

図-4：成層がない場合の PIV による実験結果 (a) と計 算結果 (b) の比較

\section{5. 実験結果の考察と計算結果の検討}

この章では, PIV 法による流速測定結果と数值計算 で得た結果との比較を行う，瞬時の PIV の結果は，過 誤ベクトルが多く含まれているために，本研究において は, 周辺 8 点の流速ベクトルの平均值よりも $\pm 50 \%$ 以 上逸脱したものは過誤ベクトルとして周辺 8 点におけ る流速の平均值で置き換えた。しかしながら，過誤べ クトルを除いただけでは，完全に流速分布からノイズ 成分を取り除くことができなかった，そこで 0.1 秒間隔 で連続して計測した結果を 75 個重ね合わせて，それを 平均してベクトル図を作成した.

成層化した場合の検討を行う前段階として, 斜面上の 風成流の特徵を捉えるために成層がない場合（淡水の み）のPIV 測定結果を計算結果と比較したものを図-4 に示す. 図-4(a) は，風応力によって水槽内が定常に循 環するまで待って（送風開始から 10 分後）測定した結 果である，流速べクトルの状況から，斜面付近でゼロ に近い流速が，斜面（底面）から離れるに従って徐々に 流速が増加していることがわかる，また，流れはほぼ 全域で斜面とある角度を持った方向を示している，次 に図-4(b) の計算結果を見ると，全体的な流れの方向 と大きさは実験結果とほぼ同様な傾向を示しているこ とがわかる。しかしながら，計算結果では底面近傍に おける流速の絶対值が実験結果と比較して過大に評価 されていることがわかる。この不一致は，実験で用い
た滑らかな斜面を数値計算では階段形状として扱った ために生じたと考えられる。また，水槽の構造上の問 題として，底面から $26 \mathrm{~cm}$ より上側にフランジがある ために PIV 法では水面付近のべクトルが得られていな い.この部分では，左から右に向かう流れが卓越する はずであるが，その流速べクトルが反転する層に近づ くにつれて流速べクトルが変化している様子は測定値 と計算値ともに一致しているのがわかる.

次に, 水槽内を 2 層に成層化した場合の PIV の測定 結果を示す，上下層の密度差が大きい場合は密度境界 面でのレーザーシートの反射が激しくなり，計測断面 で良好な画像が得られなかった。ここでは，反射の影響 が無視できる条件である上下層の密度差 $0.0025 \mathrm{~g} / \mathrm{cm}^{3}$ の場合の結果について述べる。図-5 は，送風開始から 400 秒までの両者の比較を 100 秒ごとに示している. 左 側が実験結果，右側が計算結果である．送風開始後 100 秒では, 徐々に下層水が斜面を遡上している段階であ り, 水底からの距離が $19 \mathrm{~cm}$ 以下で速度が遅い部分が下 層水塊である。この瞬間には，計測領域全体で斜面に 沿ってほぼ一方向に流れがある．数值計算から得られ た結果を実験結果と比較するとほぼ同様の傾向が得ら れていることがわかる． 200 秒後の状況は，遡上してい た下層水（底からの距離が $24 \mathrm{~cm}$ 以下の部分）がほぼ 遡上を終了し, 斜面に沿って下降を始める段階であり, 上層水が比較的大きな流速で下降してくる様子がわか る. 数值計算の結果も, 上層で流速が大きくなり, 下 層で向きを変えようとしているところなど，流れの傾 向は類似している. 300 秒後の実験結果を見ると下層水 と上層水は逆方向の流れを示し, 流況が非常に複雑に なっているのがわかる．この下層水の運動は，図-3 の 270 秒付近の内部静振による密度境界面の低下に対応し た現象と考えられる。この段階になると，強い混合が 密度境界面付近で生じているものと予想される，計算 では下降する下層水は表現されているものの複雑な流 況を表すまでには至ってない，400 秒後になると，実験 では下層水が底から $24 \mathrm{~cm}$ 付近まで再び上昇し，下層 では静止に近い状態になっているが，計算ではまだそ の状況には到達していない。

図-6 は，PIV 計測で得られた流速分布から渦度を計 算したものである．左側には正の渦度分布，右側には 負の密度分布を示してある．まず，100 秒後を見ると風 応力によって風上へ移動し始めている上下層の密度境 界面付近 (底から $19 \mathrm{~cm}$ ) と底面において正の渦度が高 くなっており，この部分で他の部分より強い剪断流が 生じているのが予測できる，200 秒後では，水底から約 $25 \mathrm{~cm}$ まで上昇した密度境界面において 100 秒の時より も高い正の渦度が示され, 底面付近では下降に転じた 下層水によって負の渦度が高くなっている． 300 秒後 
(a) 送風開始後 100 秒
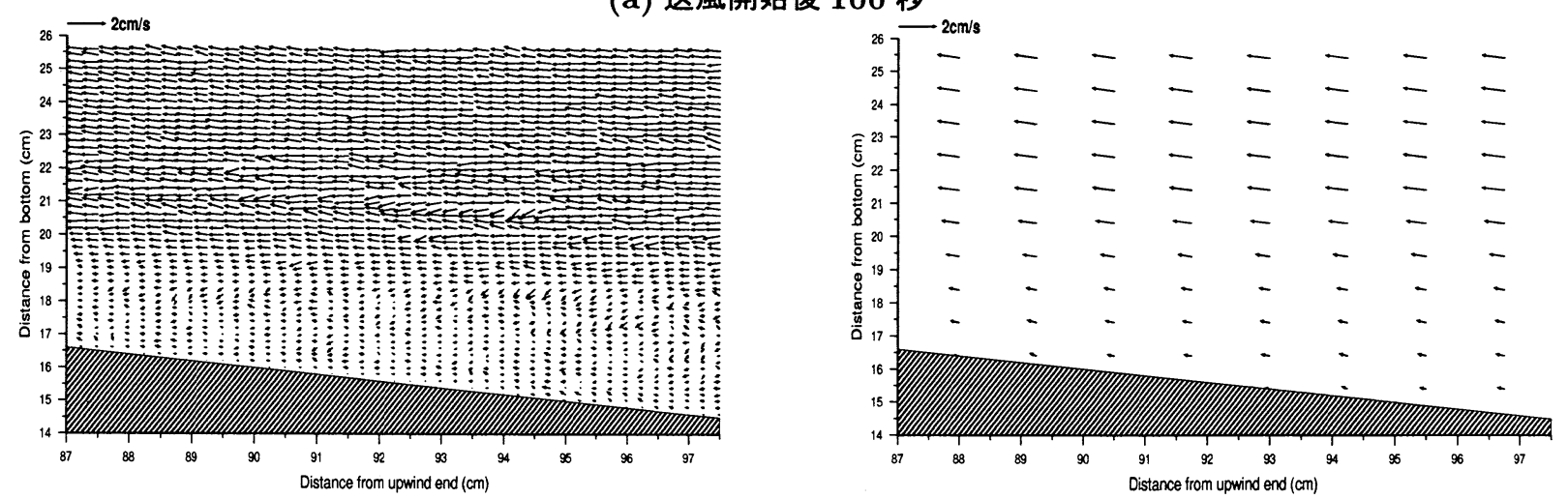

(b) 送風開始後 200 秒
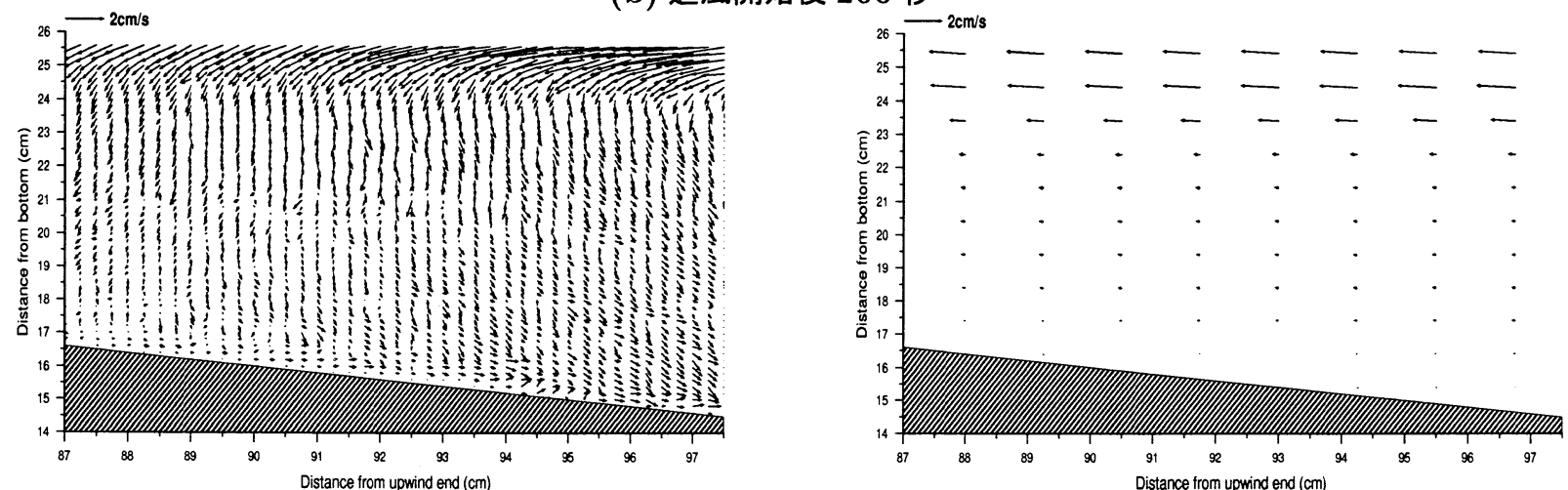

(c) 送風開始後 300 秒
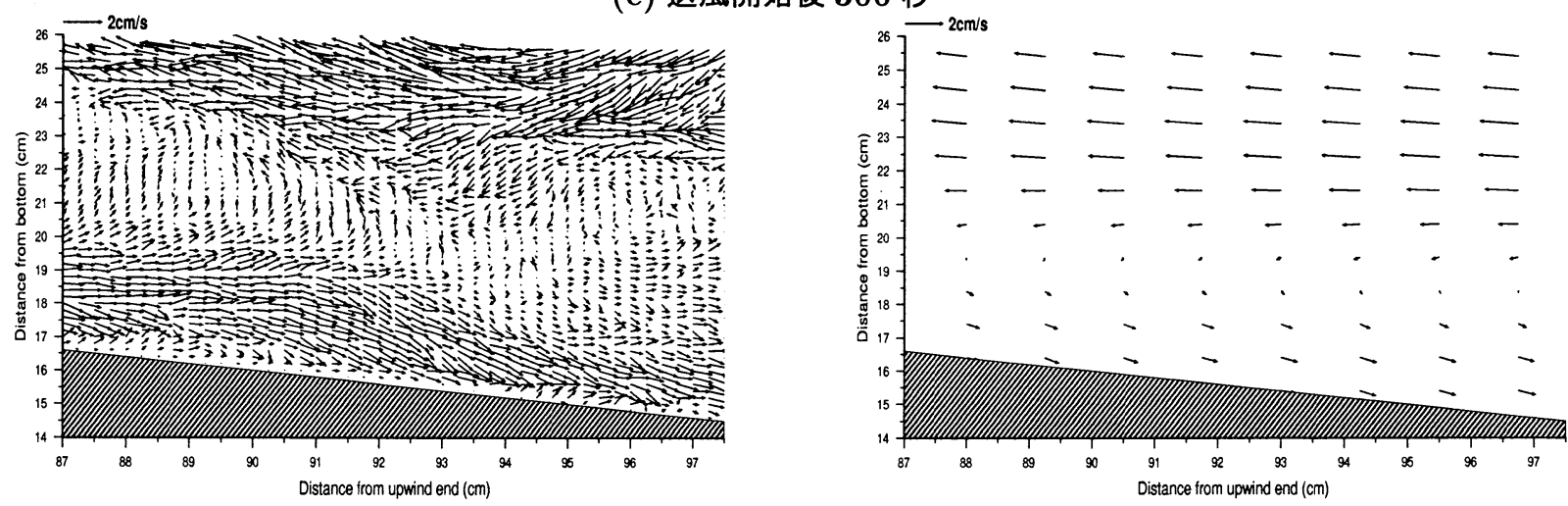

(d) 送風開始後 400 秒
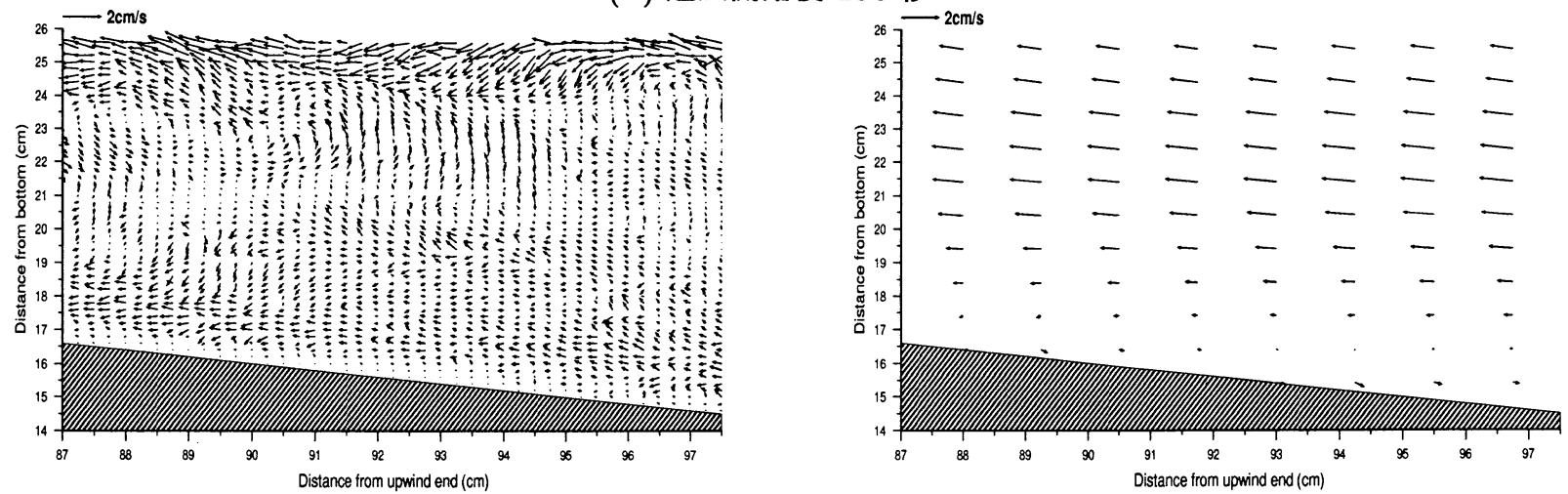

図-5：PIVによる測定結果（左）と計算結果（右）の比較 
(a) 送風開始後 100 秒

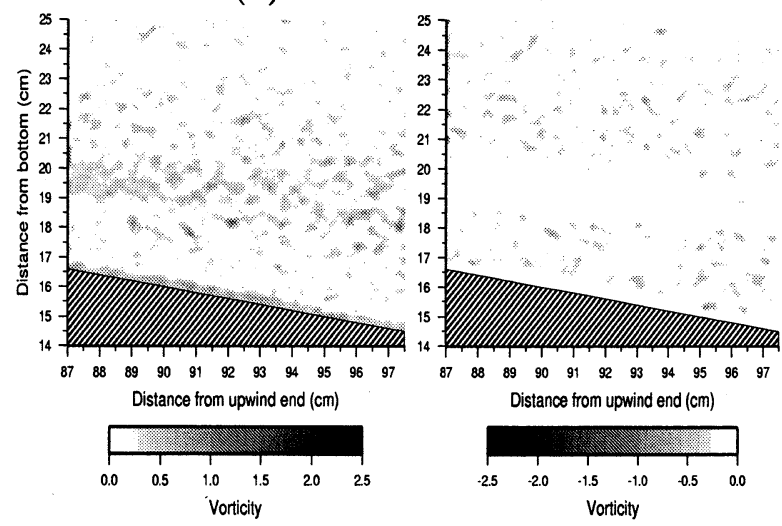

(b) 送風開始後 200 秒

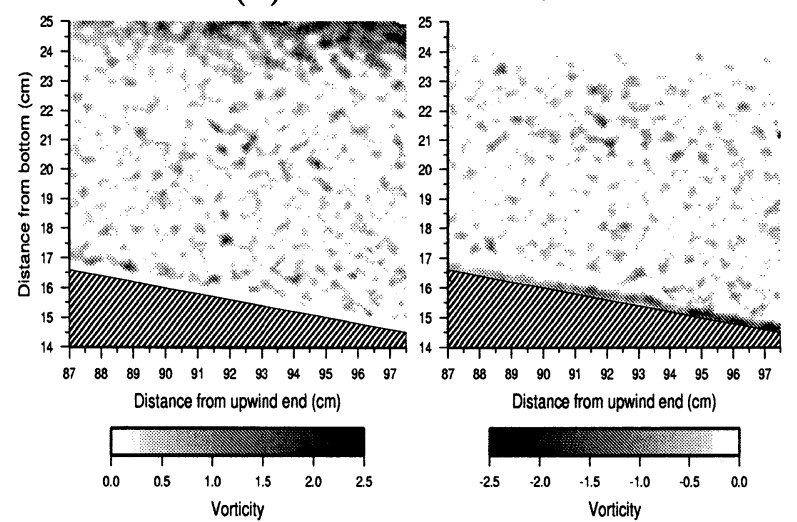

(c) 送風開始後 300 秒

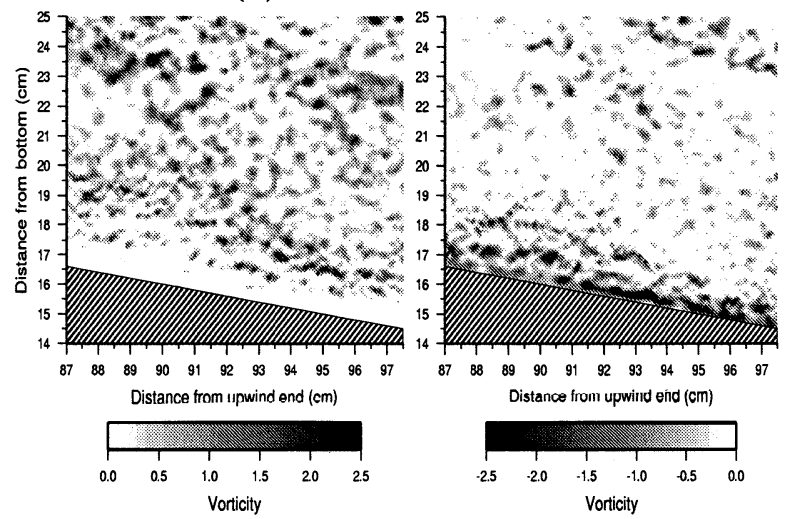

(d) 送風開始後 400 秒

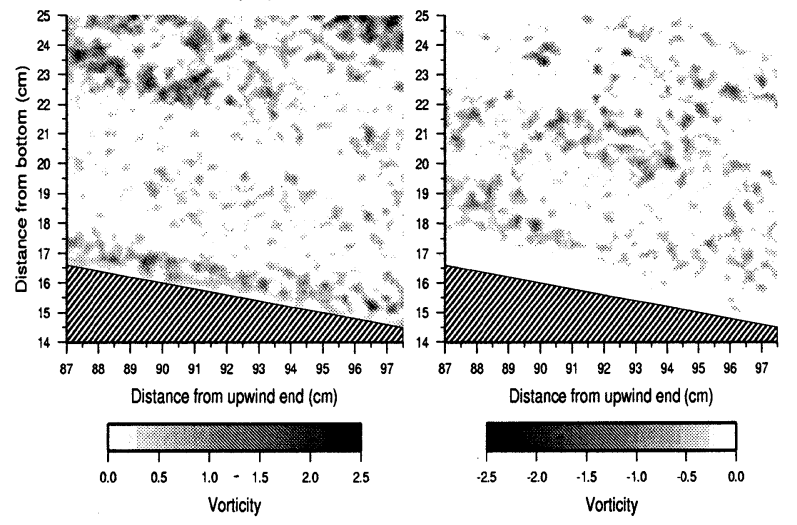

図-6 : 渦度の空間分布（左が正值，右が負值）

には，ほぼ全域で高い正の渦度になっており，強い剪断 流が生じていることがわかる，また，斜面上では下層
水の斜面下方への移動による負の渦度が高くなってい る. 400 秒後には, 再び風上に向かう下層水によって底 面部分で正の渦度が大きくなっているのがわかる．こ れらの結果から, 水域が成層している場合の初期段階 では，風によって引き起こされる循環によって様々な 部分で剪断流が非定常的に生じ, 成層混合を促進して いることが確認できた.

\section{6. まとめ}

今回の研究で得られた結論は以下の通りである.

（1） 2 層に成層した水槽内の風循環によって生じる混合 現象を画像処理によって得られた輝度分布と多チャン ネル電気伝導度計によって得られた結果を用いて比較 した，その結果，両者に良好な一致が見られ，今まで 使われてきたビデオ撮影による画像解析が 2 次元的な 混合状態を把握するための有力な手段であったことが 確認できた。

（2）密度成層場の流動は, PIV 法を用いて計測を行っ た. その結果, 湧昇時の斜面上での下層密度水塊内の 流動が把握できた。 また, 非定常的に生じる密度境界 面と底面付近の剪断流もとらえることができた。

(3) PIV 法による測定結果を数值計算結果と比較し たところ, 斜面上における上下層水の流動状況は数值 計算によって定性的に再現できていることがわかった.

\section{参考文献}

1) Kranenburg, C. : Mixed-layer deepening in lake after wind setup, J. of Hydr. Engrg., ASCE, Vol.111, No.9, pp.1279-1297, 1985.

2) 田中昌宏, 石川忠晴 : 日成層の連行則の理論的考察, 水工学論文集, 第 34 巻, pp.169-174, 1990.

3) 浦 勝 : 風の剪断力による密度界面の変動と連行速 度, 第 30 回海岸工学講演会論文集, pp.561-565, 1983. 4) 尹 鍾星 : 成層水域における貧酸素水塊の湧昇現象に 関する水理学的研究, 大阪大学工学博士学位論文, 1994 . 5) 新谷哲也, 梅山元彦: 風応力下における閉鎖二成層 水域内での中間密度層の混合特性, 水工学論文集, 第 44 巻, pp.981-986, 2000.

6) 新谷哲也, 梅山元彦: 風応力による三成層水域の応答 に関する数值解析, 水工学論文集, 第 46 巻, pp.10071012, 2002.

7) 新谷哲也, 梅山元彦 : 湧昇域の斜面が成層湖の湧昇・ 混合に与える影響, 水工学論文集, 第 47 巻, pp.11891194, 2003.

8) 新谷哲也, 梅山元彦: 風応力による三成層水域の态答 に関する数值解析, 水工学論文集, 第 46 巻, pp.10071012, 2002.

(2003.10.1 受付) 